\title{
Syntactic Configuration of Code-Switching between Indonesian and English: Another Perspective on Code-Switching Phenomena
}

\author{
Harlinah Sahib $\mathbb{D}^{1},{ }^{1}$ Waode Hanafiah $\mathbb{D}^{2},{ }^{2}$ Muhammad Aswad ${ }^{D},{ }^{3}$ Abdul Hakim Yassi $\mathbb{D},{ }^{1}$ \\ and Farzad Mashhadi $\mathbb{D}^{4}$ \\ ${ }^{1}$ Department of Cultural Science, Hasanuddin University, Makassar, Indonesia \\ ${ }^{2}$ Department of Education, Dayanu Ikhsanuddin University, Makassar, Indonesia \\ ${ }^{3}$ Department of English Education, Universitas Sulawesi Barat, Majene, Indonesia \\ ${ }^{4}$ Department of English, Isfahan (Khorasegan) Branch, Islamic Azad University, Isfahan, Iran
}

Correspondence should be addressed to Harlinah Sahib; harlina.sahib@unhas.ac.id and Farzad Mashhadi; farzadmashhadi65@gmail.com

Received 20 October 2021; Revised 4 November 2021; Accepted 17 November 2021; Published 13 December 2021

Academic Editor: Ehsan Namaziandost

Copyright ( 2021 Harlinah Sahib et al. This is an open access article distributed under the Creative Commons Attribution License, which permits unrestricted use, distribution, and reproduction in any medium, provided the original work is properly cited.

\begin{abstract}
Code-switching, an alternation or mixing one language with another, has been an unmarked phenomenon for a multilingual society. In Indonesia, this phenomenon nowadays lives and thrives among the people. This study discusses the syntactic configuration of code-switching between Indonesian and English in terms of switched segments, points, and changing types. The study is descriptive qualitative in nature. The data comprise 25 recording hours of natural speech produced by 119 Indonesians in 4 types of interaction: seminars, meetings, TV dialogues, and chitchats conducted in six metropolitan cities-Jakarta, Bandung, Semarang, Yogyakarta, Surabaya, and Makassar. The sample drawn purposively comprises 550 switching discourses consisting of 666 switching corpora. It is found that nouns serving as subjects, predicators, objects of verbs, and prepositions to be the most dominant switched segments. A switch between Indonesian noun phrases and English noun phrases, Indonesian verbs or prepositions, and English objective noun phrases, Indonesian conjunctions, and English conjoined noun phrases or clauses is the most popular switched points, and intercausal switching including intraporal and interlexical switching is the most frequent switching type of code-switching between Indonesian and English. ANOVA Friedman's test confirms that these patterns are the same among the four types of discourses, implying that such a syntactic configuration of Indonesia-English code-switching is universally applicable to any situation and type of interaction. In conclusion, the domination of nouns indicates that the syntactic configuration of Indonesian-English code-switching mainly occurs at minor constituents such as within a clause, phrase, and word boundaries. This demonstrates that code-switching between Indonesian and English is more likely to occur intrasentential rather than intersentential, which is the most popular anywhere in literature.
\end{abstract}

\section{Introduction}

In a multilingual society, people are prone to employing more than one language in communication. Consequently, they frequently alternate from one language to another or mix one language with another whenever they communicate. Such an alternation, called code-switching or codemixing, has been an unmarked phenomenon for a multilingual society. It is even believed that almost no single country in the world can escape from this phenomenon. This is because the phenomenon covers not only an interlingual switch, a switch from one language to another, but also it covers an intralingual switch, an alternation within one language, for example, from a standard register to a nonstandard one or vice versa or a shift from high-class variety to lower class one or vice versa. This latter case can be found in the Javanese language, a language primarily spoken in Java. This language recognizes three social class varieties: "Ngoko" (lower class), "Madya" (middle class), and "Krama" (high class). Rahardi [1], in his study on code-switching among these three varieties made by Javanese people when they communicate with others in a traditional market in 
Yogyakarta, found that the switch occurs systematically and is governed mainly by the social status of the interactants.

In Indonesia, as a multilingual country, this phenomenon thrives among Indonesian people. It is pretty easy for us to find people switching or mixing their Indonesian with some English expressions whenever they communicate with others. Alternating from Indonesian to English or mixing Indonesian and English during communication seems to have become a new trend for Indonesian people, primarily in metropolitan cities such as Jakarta, Bandung, Semarang, Surabaya, and Makassar. Emilia and Widiadana in "The Jakarta Post" (July 2, 2000) pointed out that Indonesian people starting from the President of Indonesia to business executives, celebrities, housewives, teenagers, and children are employing English phrases in their daily activities as follows:

(i) Guetadi (I had just) LUNCH MEETINGsamabos(with boss)

(ii) Enak lu ya. Gue mestiketemu (Good for you, I had to see)CLIENT, ada (there was) APPOINTMENT pagi-pagi (early in the morning)

(iii) Guehampirtelat, (I almost came late) YOU KNOW, TRAFFIC JAM

Of course, this phenomenon has provided sociolinguists with a new and challenging perspective for the study on code-switching in general and Indonesian-English codeswitching in particular. Moreover, the examples of switching discourses above raise several issues, including competence in multilingual individuals and communities, the social dimension of code-switching, pragmatic functions of codeswitching, or the linguistic configuration of code-switching. Sociolinguists have endlessly investigated all these aspects all over the world. The present study will, however, not aim to discuss such an exhaustive coverage. Instead, it will be geared toward investigating the syntactic configuration of code-switching between Indonesian and English. Thus, this study attempts to figure out general patterns of syntactic features of code-switching between Indonesian and English, especially in terms of switched segments, points where switches are likely to occur, and changing types.

When we trace back to previous studies on codeswitching, the researcher found much progress has been made in situating code-switching within a microsociological framework or that of ethnography of speaking, consistent with the goals of understanding the interactive purpose, communicative function, and social implications of this code alternation behavior, for instance, to name only a few, Setiawan [2]; Gumperz [3, 4], Sankoff [5, 6]; Denison [7]; Motschenbacher [8]; Marasigan [9]; Li [10]; and Widaya [11]. Similarly, a significant number of studies on codeswitching have focused directly on the linguistic aspects, especially syntactical or grammatical aspects of codeswitching, for instance, to name only a few, Hasselmo [12, 13], Schiegg [14]; Gingras [15]; Amuzu [16]; Timm [17, 18], and Mokgwathi and Webb [19]. Of course, such progress has been of outstanding contribution to the studies of code-switching in the world. None of these studies, however, have accounted for a code alternation between
Indonesian and English. The writer found that studies on code-switching between Indonesian and English have not been extensively explored. Thus, apart from unpublished papers, there is not much literature on studies on codeswitching between Indonesian and English. Therefore, the present study aimed to fulfill such a gap.

\section{Method}

2.1. Research Design. The present study, descriptive qualitative, and quantitative relies entirely on a content-based analysis assisted by a statistic test, ANOVA Friedman, aimed at testing whether or not the patterns of the syntactic configuration of Indonesian-English code-switching to be the same among the four types of discourses: seminar, meeting, TV dialogue, and chitchat discourses. Moreover, the present study has designated four types of speech interactional discourses: seminar, meeting, TV dialogue, and chitchat discourses to be the independent variables. In comparison, the syntactic configuration includes switched segments points where a switch is likely to occur and changing types of Indonesian-English code-switching to be the dependent variables of the present study.

\subsection{Subjects: Nature, Number, and Bilingual Competence.} The present study involves 119 subjects from different professions such as technocrats, bureaucrats, lecturers, and business people residing in Indonesia's metropolitan cities such as Jakarta, Bandung, Semarang, Yogyakarta, Surabaya, and Makassar. In general, the subjects' working knowledge of English ranges from relatively fair to excellent. Some have enjoyed studying in an English-speaking country, and others have resided in an English-speaking country for a business matter. The term "semi-bilingualism" defined by Hockett [20] is suitable for classifying the subjects' bilingual competence.

2.3. The Data: Nature, Source, Collection, Population, and Samples. The present study's data comprises 25 recording hours of natural speech taken from 26 events in Jakarta, Bandung Semarang Yogyakarta, Surabaya, and Makassar from 2000 to 2002. From such a population, it has been drawn purposively 550 switching discourses comprising 666 switching corpora.

2.4. Instrument and Equipment. The present study utilizes a questionnaire to get information on the respondent's autobiography, especially their educational background and length of stay in an English-speaking country. Moreover, two minicassette recorders, Sony TCM 459v and Sony TCM 77 with VOR feature functioning, to improve the quality of the recording are used as equipment to record the utterance in the four-speech interaction mentioned above.

2.5. The Analysis Technique. At first, the recorded data are transcribed and then select discourses containing the switching instances. These switching corpora are then put in 
a tabular form based on their categories, for example, switched segment, switched points, and types of switching. The frequency of occurrences of these linguistic features is then calculated. Finally, they are then tabulated against the four classes of discourses: seminars, meetings, TV dialogues, and chitchats employing a statistic test, the ANOVA Friedman test.

\section{Findings and Discussion}

3.1. Switched Segments. The study found nouns (N) which were made up of noun phrases (NP) as in (1), single noun $(\mathrm{N})$ as in (2), objective noun phrases (Obj, NP) as in (3), predicative noun phrases (Pred. NP) as in (4), and subjective noun phrases (Subj. NP) as in (5) to be the most dominant switched segments in the four variables: seminar, meeting, TV dialogue, and chitchat discourses, comprising more than three-fourth of the data $(80,1 \%)$.

(1) STATE OF THE ART pariwisata (tourism) di suatu negara merupakan interaksi antara dua kekuatan yaitu sisi permintaan dan penawaran (in a country is the interaction between two forces namely aspects of demanding and offering) (J006/sp1)

(2) Pada suatu kesempatan (in one moment)BREAKFAST saya memesan telur setengah matang kepada pelayan (I ordered half-cooked egg from a waitress) .(L028/sp4)

(3) Hal itudiupayakanuntukmendapatkankesetaraanbu daya(It is intended to obtain cultural equality) CULTURAL EQUALITY. (L016/sp3)

(4) Salah satujenispenelitianiniadalah(one of the types of the study is)PARTICIPATION ACTION RESEARCH (N003/sp1)

(5) BUSINESS MEETINGdiawali oleh ketuasidang(was initiated by the meeting leader) (N010/sp2)

It is then followed by adjectives (Adj)as in (6), which are made up of predicative adjectives (Pred. Adj) and attributive adjectives (Attr. Adj) comprising almost one-tenth of the data $(8.6 \%)$, and verbs containing $4.8 \%$ of the data as in (7)

(6) Pembangunan selamainihanyamenciptakanmanusia yang (the development done so far simply creates men who) DEPENDENT tidak punya etos(and do not have ethos)SURVIVAL yang tinggi(which is high) (J043/sp1)

(7) Bagaimanakitabisa(How could we) men-( $\varnothing$ ) DEVELOPsuatu(a)PRODUCT (S013/sp2)

The detailed illustration of the switched segments found by the present study can be seen in Table 1 .

The following figure (Figure 1) displays a much more transparent illustration of the dominant switched segments of codeswitching between Indonesian and English found in the four types of speech interactional discourses; seminars, meetings, TV dialogues, and chitchats.

The ANOVA test confirms no significant difference in the switched segments found among the four variables; seminar, meeting, TV dialogue, and chitchat discourses (35.34, <table value in both 0.01 and 0.05 levels, i.e., 40.11 and 47.00, respectively, giving $H_{0}$ is accepted). This implies that this phenomenon, where nouns were found to be the most frequent switched segments of Indonesian-English code-switching, can be said to be universally applicable to any other situation and form of interaction.

Moreover, this finding has convincingly supported other previous studies, such as to name only a few studies such as Yassi [21]; McClure [22]; Poplack [23]; and Timm [17], where the noun is found to be the most frequent switched segment. At the same time, however, the finding has virtually provided a counterargument to Poplack's [23] conclusion revealing that the higher the syntactic level of constituents, the greater the probability that it will be switched. Thus, he claimed that the switch was more likely to occur in more significant sentences than smaller ones such as clauses or phrases. In contrast, as clearly illustrated above, the present study has demonstrated that code-switching between Indonesian and English is more likely to occur at more minor constituents such as within a clause and phrasal boundaries.

When this finding is compared with those found in the English-based code-switching, where English is the matrix language (ML) and Indonesian is the embedded language (EL), the two studies show highly different finding behavior. Nouns are the most frequently switched segments in Indonesian-based code-switching (Indonesian as the ML and English as the EL). In contrast, in English-based codeswitching, clauses (both independent and dependent clauses) are the most dominant switched segment, comprising almost three-fourth of the data (73.8\%). Table 2 clarifies this.

To explain this phenomenon more straightforwardly, I have put the features in a pie diagram in Figure 2.

As can be seen from Figure 2, independent clauses are the most dominant switched segment in English-Indonesian code-switching (EICS), taking almost three-fourth of the data $(73.8 \%)$. It is then followed by nouns and fillers, comprising $11.9 \%$, respectively. This phenomenon suggested that the Indonesian respondents tend to switch in much larger code-switching between English and Indonesian (abbreviated as EICS). English is the host language, and Indonesian is the guest language.

I assume such different behaviors are more likely to motivate the speakers' competence in the embedded language. In English-based code-switching, the EL is Indonesian. Since the study subjects are native speakers of Indonesian, they found it more convenient and much easier for them and more free to use the language in any level of constituents. As a result, code-switching is more likely to occur in extensive components such as sentential boundary and a clausal boundary without fearing violating either language grammatical system. In contrast, such ease may not exist in Indonesian-based code-switching (IECS) because the EL is English. The subjects have a limited linguistic property in expressing the specific idea in English due to a lack of competence. Therefore, avoiding ruining either language grammatical system, the respondents would prefer to switch code in a minor constituent instead of within a clausal boundary, a phrasal border, or even a linguistic boundary. 
TABLE 1: The switched segments of seminars, meetings, TV dialogues, and chitchats.

\begin{tabular}{|c|c|c|c|c|c|c|}
\hline \multirow{2}{*}{ No. } & \multirow{2}{*}{ Switched segments } & \multicolumn{4}{|c|}{ Speech interactions } & \multirow{2}{*}{ Total } \\
\hline & & Seminars & Meetings & TV dialogues & Chitchats & \\
\hline 1. & Subj. N (NP) & $7(1.9 \%)$ & $7(4.5 \%)$ & $9(12.9 \%)$ & $3(8.1 \%)$ & $26(4.2 \%)$ \\
\hline 2. & Pred. N (NP) & $13(3.6 \%)$ & $19(12.2 \%)$ & $7(10 \%)$ & $3(8.1 \%)$ & $42(6.7 \%)$ \\
\hline 3. & Obj. N (NP) & $45(12.5 \%)$ & $28(17.9 \%)$ & $15(21.4 \%)$ & $6(16.2 \%)$ & $94(15.1 \%)$ \\
\hline 4. & Single N & $89(24.7 \%)$ & $24(15.4 \%)$ & $11(15.7 \%)$ & $3(8.1 \%)$ & $127(20.4 \%)$ \\
\hline 5. & NP & $16345.2 \%)$ & $36(23.1 \%)$ & $6(8.6 \%)$ & $5(13.5 \%)$ & $210(33.7 \%)$ \\
\hline 6. & Verb (VP) & $10(2.8 \%)$ & $16(10.3 \%)$ & $1(1.4 \%)$ & $3(8.1 \%)$ & $30(4.8 \%)$ \\
\hline 7. & Idiomatic expr. & 0 & $3(1.9 \%)$ & 0 & 0 & $3(0.5 \%)$ \\
\hline 8. & Prep. P & 0 & $1(0.6 \%)$ & 0 & $1(2.7 \%)$ & $2(0.3 \%)$ \\
\hline 9. & Pred.Adj. (Adj.P) & $6(1.7 \%)$ & $10(6.4 \%)$ & $5(7.1 \%)$ & $3(8.1 \%)$ & $24(3.8 \%)$ \\
\hline 10. & Attributive Adj. & $20(5.5 \%)$ & $3(1.9 \%)$ & $6(8.6 \%)$ & $1(2.7 \%)$ & $30(4.8 \%)$ \\
\hline 11. & Indep.Clause & $6(1.7 \%)$ & $4(2.6 \%)$ & $4(5.7 \%)$ & $5(13.5 \%)$ & $19(3.0 \%)$ \\
\hline 12. & Tag & 0 & $2(1.3 \%)$ & $2(2.9 \%)$ & 0 & $4(0.6 \%)$ \\
\hline 13. & Adv. & 0 & 0 & $1(1.4 \%)$ & 0 & $1(() .2 \%)$ \\
\hline 14. & Dep.Clause & $2(0.6 \%)$ & $1(0.6 \%)$ & $2(2.9 \%)$ & $1(2.7 \%)$ & $6(1.0 \%)$ \\
\hline 15. & Pro. & 0 & $1(0.6 \%)$ & 0 & $2(5.4 \%)$ & $3(0.5 \%)$ \\
\hline 16. & Interjection & 0 & 0 & 0 & $1(2.7 \%)$ & $1(0.2 \%)$ \\
\hline 17. & Minor clause & 0 & $1(0.6 \%)$ & $1(1.4 \%)$ & 0 & $2(0.3 \%)$ \\
\hline Total & & 361 & 156 & 70 & 37 & 624 \\
\hline
\end{tabular}
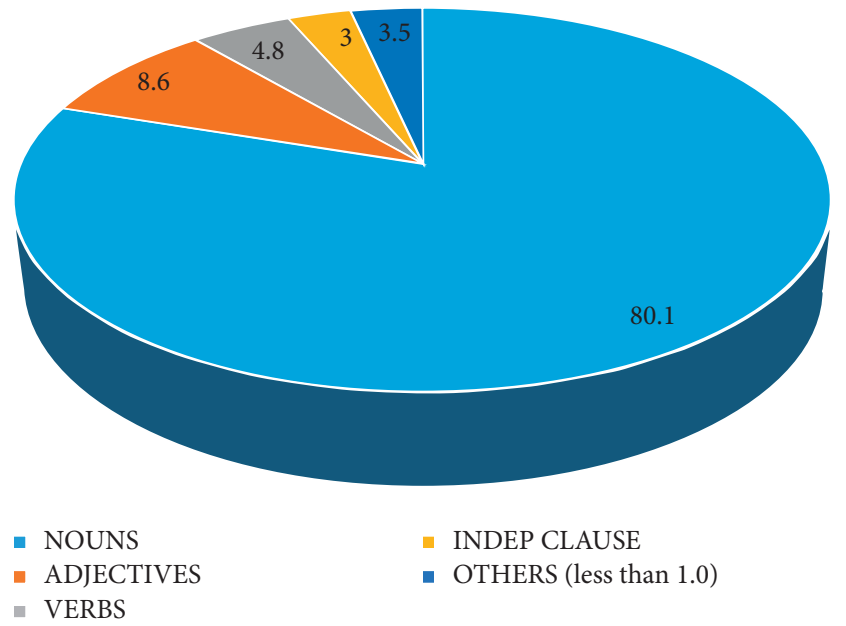

FIgURE 1: The dominant switched segments of IECS.

TABLE 2: The switched segments of English-Indonesian codeswitching.

\begin{tabular}{lccccc}
\hline \multirow{2}{*}{ Switched segments } & \multicolumn{3}{c}{ Sample codes } & \multirow{2}{*}{ Total } & $\%$ \\
& $\mathrm{H}$ & $\mathrm{W}$ & $\mathrm{Z}$ & & \\
\hline Single N & - & 2 & - & 2 & 4.8 \\
NP & 2 & 1 & - & 3 & 7.1 \\
Pred. adj. (Adj.P) & - & - & 1 & 1 & 2.4 \\
Indep. clause & 12 & 14 & 4 & 30 & 71.4 \\
Dep. clause & - & 1 & - & 1 & 2.4 \\
Filler & 4 & 1 & - & 5 & 11.9 \\
Total & 18 & 19 & 5 & 42 & 100 \\
\hline
\end{tabular}

Now, it is time to get back to the point of switched segment in IECS. I believe that at least three essential factors motivate this noun domination. Firstly, the natural portion of the noun in the structure of English sentences. Noun

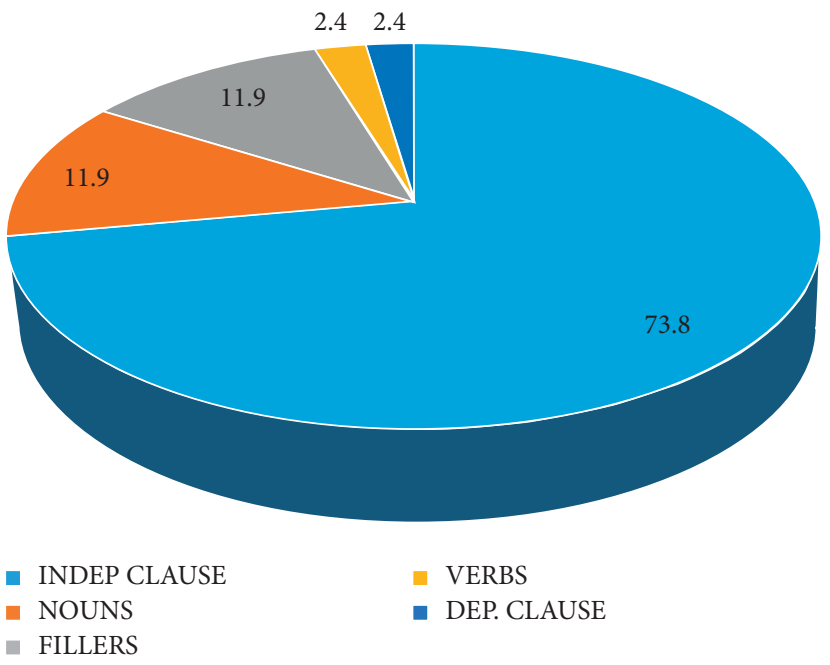

FIGURE 2: The dominant switched segments of EICS.

occupies about two-third of the syntactic roles of an English sentence, i.e., subjects and objects of both verbs and prepositions. Secondly, low intensity of use. English is only used occasionally as a foreign language, in classrooms, and only among certain groups. Yassi [24] detected on average only 0.30 switches to English per minute made by Indonesians. This figure is relatively small compared to Gumperz's data [4] on code-switching between Spanish and English in New York. He found his respondents do one switch per minute. Thus, the discrepancy of the two studies' switching per minute is more than three times. Finally, the domination of nouns can also be something to do with the speaker's English competence. Due to their lack of English competence, subjects tend to switch only in trim constituent levels rather than major ones. Otherwise, they will risk ruining the syntactic categories of both English grammar and structure. 
This is in line with Yassi [25]; who is concerned with Indonesian students' poor competence at the tertiary and secondary levels. Likewise, Maming [26] concluded that most Indonesian students lack speaking and writing competencies due to low learning motivation.

Similarly, Romaine [27] pointed out that switchers tend to switch nouns free from syntactic restriction. Switchers felt free to change without fearing violating the form of embedded language. Another theory supporting this phenomenon can be the "chunk" theory by Azuma [28], stating that a word that can meaningfully stand alone can be switched. Similarly, "open and closed class item" theory by Joshi [29] claims that only open class items such as nouns, verbs, adjectives, and the likes can be switched as they are content words while the closed one such as a determiner, prepositions, possessive, auxiliary, and tense cannot be exchanged as they are operative words. Another theory has been the "islandhood" theory by Myerz-Scotton [30], suggesting that a switch for a noun phrase may only occur when the whole segments of the words are switched. Otherwise, it will ruin the intact of the phrase. It seems to be nouns have met all criteria revealed by these theories. Therefore, nouns are entitled to have the ability to be switched.

3.2. Switched Points. The study has discovered twenty-two switched points of Indonesian-English code-switching in the four types of discourses; seminars, meetings, TV dialogues, and chitchats. Table 3 shows a detailed illustration of these switched points. It is found the switch occurred between Indonesian noun phrases (NP) and English noun phrases $(\mathrm{NP})$ as in (8), between Indonesian verbs(V) and English objective noun phrases (Obj. NP) as in (9), and between Indonesian conjunctions (Conj) and English noun phrases (NP) as in (10) to be the most dominant switched points, comprising $21.6 \%, 14.6 \%$, and $8.5 \%$, respectively, of the data. For example,

(8) Salah satuciriutama GOOD GOVERNANCEadalahadanyahubungan yang simetrisantarapemerintah, pasar, dan masyarakatsipil (J034/sp1)

(9) Justruinimemberikan SATISFACTION yang tinggi (R017/sp2)

(10) Olehnyaitukitamengembangkansuatupendekatan yang lain, bukan MARKET EVENT tetapi MARKET AGREEMENT (R014/sp2)

Even though the study's findings, especially the most popular combinations of switched points, is the switching between Indonesian NP and English $\mathrm{NP}$, between Indonesian V and English Obj. NP, between Indonesian Conj. and English NP, and between Indonesian Prep and English NP have lent strong support to other previous similar studies such as Gumperz [3, 31], Timm [17]; Poplack [23]; and Yassi [21]; there are still plenty rooms for counterexamples to the previous studies found in this study (for example, the segments under consideration are underlined).
Proposed constraints: switching is restricted between pronominal subjects or objects and verbs ([31]:158; [17]:477).

(11) Counter example:

Takmungkinkitabisamembenahisesuatukalaukita LOOSING CONFIDENCE (B001/sp1).

As can be seen from the example above, the word " $k i t a$ " is an Indonesian pronoun denoting the firstperson plural is immediately followed by an English verb "loosing." This indicates that the switched point of this sentence is between pronoun and verb, giving an illustration that the universality of proposed constraint above is questionable. Let consider other following restrictions.

Proposed constraints: switching is blocked between auxiliary and verbs ([17]:478).

(12) Counterexample:

Saya bisa CONVINCING PEOPLE denganbahasa Makassar (V004/sp2).

As can be seen from the example above, the Indonesian modal auxiliary, "bias" (can), is immediately followed by an English verb, "convincing." This indicates that the switch occurs between auxiliary and verb. The proposed constraint claiming that switching is blocked between auxiliary and verb is not universally applicable.

Proposed constraint: the conjunction must be in the same code as the conjoined sentence ([32]:34).

(13) Counterexample:

Terus terang, sayabukanmemFLATTERkarena FLA TTERY WILL TAKE YOU NOWHERE (E036/sp1).

The example denotes the Indonesian conjunction, "karena" (because) is immediately followed by an English clause, "flattery will take you nowhere." This illustrates that the switch occurs between conjunction in Indonesian and the conjoined sentence or clause in English. This again confirms that the proposed constraint is not universally applicable.

Based on the examples above, there appears to be the universality of some previous theories on constraints of code-switching, especially Sankoff and Poplack's two grammatical constraints theory on code-switching, "free morpheme constraint" predicting that a switch may not occur between a bound morpheme and a lexical form unless the linguistic form has been phonologically integrated into the language of the morpheme, and "the equivalence constraint" predicting that a switch will tend to occur at points where the juxtaposition of elements from the two languages does not violate a syntactic rule of either language is under the question mark. This theory does not have strong support from the data of the present study. Thus, this theory is not universally applicable. Moreover, even though "the equivalent constraint theory 
TABLE 3: The switched points of seminars, meetings, TV dialogues, and chitchats of Indonesian-English code-switching.

\begin{tabular}{|c|c|c|c|c|c|c|}
\hline \multirow{2}{*}{ No. } & \multirow{2}{*}{ Constraints and switched points } & \multicolumn{4}{|c|}{ Speech interactions } & \multirow{2}{*}{ Total } \\
\hline & & Seminar & Meeting & TV dialogues & Chitchat & \\
\hline 1 & Btw VP and Obj. NP & $49(13.6 \%)$ & $22(14.1 \%)$ & $17(24.3 \%$ & $3(8.1 \%)$ & $91(14.6 \%)$ \\
\hline 2 & Btw Conj and NP & $40(11.1 \%)$ & $7(4.5 \%)$ & $5(7.1 \%)$ & $1(2.7 \%)$ & $53(8.5 \%)$ \\
\hline 3 & Btw Conj and Adj. & $11(3.1 \%)$ & $2(1.3 \%)$ & $1(1.4 \%)$ & 0 & $14(2.2 \%)$ \\
\hline 4 & Btw Prep P and NP & $33(9.1 \%)$ & $8(5.1 \%)$ & $3(4.3 \%)$ & $3(8.1 \%)$ & $47(7.5 \%)$ \\
\hline 5 & Btw NP and NP & $105(29.1 \%)$ & $23(14.7 \%)$ & $5(7.1 \%)$ & $2(5.4 \%)$ & $135(21.6 \%)$ \\
\hline 6 & Btw NP and Prep. P & $5(1.4 \%)$ & $1(0.6 \%)$ & 0 & 0 & $6(1.0 \%)$ \\
\hline 7 & Btw NP and Pred. NP & $1(0.3 \%)$ & $5(3.2 \%)$ & 0 & $1(2.7 \%)$ & $7(1.1 \%)$ \\
\hline 8 & Btw NP and HL suffix & $9(2.5 \%)$ & $21(13.5 \%)$ & $1(1.4 \%)$ & $6(16.2 \%)$ & $37(5.9 \%)$ \\
\hline 9 & Btw NP and attributive Adj. & $6(1.2 \%)$ & $2(1.3 \%)$ & $6(8.6 \%)$ & $2(5.4 \%)$ & $16(2.6 \%)$ \\
\hline 10 & Btw Adv and VP & $1(0.3 \%)$ & $5(3.2 \%)$ & 0 & 0 & $6(1.0 \%)$ \\
\hline 11 & Btw Adv and Pred. Adj & $1(0.3 \%)$ & $7(4.5 \%)$ & $3(4.3 \%)$ & $2(5.4 \%)$ & $13(2.1 \%)$ \\
\hline 12 & Btw Adv and NP & $17(4.7 \%)$ & $11(7.1 \%)$ & $3(4.3 \%)$ & 0 & $31(5.0 \%)$ \\
\hline 13 & Btw Adj and NP & $13(3.6 \%)$ & $8(5.1 \%)$ & $1(1.4 \%)$ & 0 & $22(3.5 \%)$ \\
\hline 14 & Btw Pro and VP & $2(0.6 \%)$ & $1(0.6 \%)$ & $1(1.4 \%)$ & $2(5.4 \%)$ & $6(1.0 \%)$ \\
\hline 15 & Btw IndepCla and Indep clause & $4(1.1 \%)$ & $4(2.6 \%)$ & $1(1.4 \%)$ & $2(5.4 \%)$ & $11(1.8 \%)$ \\
\hline 16 & Btw IndepCla and NP & $21(5.8 \%)$ & $3(1.9 \%)$ & $3(4.3 \%)$ & $2(5.4 \%)$ & $29(4.7 \%)$ \\
\hline 17 & Btw IndepCla and Tag & 0 & $2(1.3 \%)$ & $1(1.4 \%)$ & $1(2.7 \%)$ & $4(0.6 \%)$ \\
\hline 18 & Btw IndepCla and Pred. Adj & $2(0.6 \%)$ & 0 & $1(1.4 \%)$ & 0 & $3(0.5 \%)$ \\
\hline 19 & Btw HL Prefix and VP & $6(1.2 \%)$ & $8(2.2 \%)$ & 0 & $2(5.4 \%)$ & $16(2.6 \%)$ \\
\hline 20 & Btw Indef Art and NP & $4(1.1 \%)$ & 0 & $2(2.9 \%)$ & 0 & $6(1.0 \%)$ \\
\hline 21 & Btw Dem and NP (Pred.NP) & $3(0.8 \%)$ & $1(0.6 \%)$ & $1(1.4 \%)$ & $1(2.7 \%)$ & $6(1.0 \%)$ \\
\hline 22 & Btw Copula and NP & $10(2.8 \%)$ & $4(2.6 \%)$ & 0 & 0 & $14(2.2 \%)$ \\
\hline
\end{tabular}

seems to be compatible to the data of the present study," especially for her argument claiming that code-switching can only occur at points where the two languages shared the same surface structure, some switching instances still show counterexamples, especially to the aspect of the violation of English grammatical system.

(14) Kita buat MOU dengan TRAVEL TRAVEL AGENCY (E034/sp1)

The reduplication of the word "travel" shows a violation of the English grammatical system. Such repetition is only applied in the Indonesian grammatical system to pluralize the word "travel." Thus, the argument claiming that code-switching can only be performed by a qualified bilingual is also questionable. Other examples of such a violation are as follows.

(15) Penggarapan AIRPORT Adi Sumarnosebagai AIR PORT INTERNATIONAL perlumendapatpehatian yang serius (K016/sp5)

This sentence also denotes an English grammatical violation, in this respect, the English word order. In English, the head (noun), airport, should follow the adjective, international, while this is reversed in the Indonesian language. Similarly, even the free morpheme constraint is the worst. The data show pretty large portions of the application or Indonesian bound morphemes into the English free morphemes.

(16) Saya fikir WAY OUTnyalebihbaikdibagidua (E008/ sp1)
(17) Saya ditugasiuntukmeMODERATORiseksionini (S 002/sp1)

(18) Saya justrumaudiFEEDBACK (I004/sp1)

When this combination of the switched points is compared with those found in English-based code-switching, it shows a relatively different feature. In English-based code-switching, most combinations are dominated by independent clauses, namely, the switch between independent clause and dependent clause, comprising half of the data. Table 4 shows a detailed illustration of the switched points of code-switching between Indonesian and English.

Again, this is not surprising since independent clauses, as mentioned previously, are the most frequently switched segments found in English-based code-switching. Again, this difference is what the researcher believes due to the subjects' mastery of the embedded languages (EL).

The ANOVA Friedman test confirms a significant difference in switched combination among the four variables (= 103.85, >the table value in both 0.05 and 0.01 levels, i.e., 79.08 and 88.40 , respectively, given that $H_{0}$ is refused). This implies that this figure still provides room for a difference. The patterns of switched points found in this study may not be the same in other different discourse types.

If we take a closer look at Table 4 above, it is found that there is an uneven distribution of the switched point combinations. The big five combinations in seminar discourses, the switch between NP and NP, VP and Obj.NP, Conj and NP, Prep and NP, and Indep Clause and NP are not necessarily the same as the big five in meeting, TV dialogue, and chitchat discourses. The big five in Meetings have been the switch between NP and NP, VP and Obj NP, NP and HL Suffix, Adv and NP, and Adj and NP. It is proved 
TABLE 4: The constraints and switched points of English-Indonesian code-switching.

\begin{tabular}{lcccccc}
\hline \multirow{2}{*}{ Constraints and switched points } & \multicolumn{3}{c}{ Sample codes } & \multirow{2}{*}{ Total } & $\%$ \\
& $\mathrm{H}$ & $\mathrm{W}$ & $\mathrm{Z}$ & & \\
\hline Btw IndepCla and IndepCla & 12 & 7 & 2 & 21 & 50.0 \\
At speaking turn & - & 4 & 2 & 6 & 14.3 \\
Btw IndepCla and NP & 2 & 3 & - & 5 & 11.9 \\
Btw Adv and IndepCla & - & - & 1 & 1 & 2.4 \\
Btw IndepCla and Filler & 4 & 1 & - & 5 & 11.9 \\
Btw NP and IndepCla & - & 4 & - & 4 & 9.5 \\
Total & 18 & 19 & 5 & 42 & 100 \\
\hline
\end{tabular}

that these last three combinations are not included in the big five in Seminars. The big five in TV dialogues show that the switch between NP and Adj, the second-largest, is absent in both the big five in seminar and meeting discourses. And likewise, in chitchats, the switch between NP and HL suffix, which is the largest, is not included in the big five in seminar and TV dialogue discourses and so forth.

3.3. Types of Code-Switching. The study has found five patterns of switching types of code-switching between Indonesian and English. For a detailed illustration of these switching types (see Table 5). It is found intraclausal switching as in (20), a switch that occurs within a clause boundary, to have the largest corpora, comprising more than a half of the data (58.8\%). It is then followed by intraphrasal switching as in (21), a switch taking place within a phrase boundary, comprising more than one-fourth of the data (26.6\%) and intralexical switching as in (22). This switch occurs within a word boundary, comprising almost onetenth of the data $(9.6 \%)$. Thus, this figure indicates that the control is more likely to occur in more minor constituents within clausal and phrasal boundaries. Even within a lexical boundary rather than minor components, such sentences comprise about $95 \%$ of the data. At the same time, the rest occur in more significant constituents, interclausal switching as in (23) comprising only $5 \%$ of the data.

(19) Pariwisatakerakyatan COMMUNITY BASED TOU RISM memilikikarakteristiktertentu (T006/sp1).

(20) Menurutpembicara, banyaknya PLANNING RESEARCH, kurangnya MARKETING ECONOMIC RESEARCH dan lain sebagainyatidakterlepasdariaspek INTEREST (S025/sp1)

(21) BagaimanakitabisamenDEVELOPsuatu PRODUCT (S011/sp2)

(22) Saya bisakatakan THE MORE GLOBAL WE BECOME, THE MORE TRIBAL WE ACT (T011/sp2)

The following figure displays a much clearer picture of the types of code-switching found in the present study.

As can be seen from Figure 3, intraclausal is the most dominant type of code-switching in IECS, occupying more than half of the data. Intraphrasal and intralexical switching types then follow it. This phenomenon indicated that Indonesian people tend to switch to a much more minor constituent. The three types of switching are categorized under intrasentential switching; the switch occurs within the sentence boundary, such as clauses, phrases, and lexis.

This finding has lent strong support to Yassi's [21] study, which found that almost all switches that occur in his data belong to the control in minor constituent, comprising 98.6\% of the data. And at the same time, it provided a counterexample to the previous similar studies. Poplack's study [23] claimed that the switch is more likely to occur only in a more prominent constituent than a smaller one. Similarly, the present study also challenged Romaine's work [27] which proclaimed the domination of intersentential switching, a switch that occurs in significant constituents such as sentences, over the intrasentential ones, an alternation occurring in minor components such as within a clause boundary, phrase, and word boundaries. The domination of intrasentential switching found in this study has also lent strong support to Treffers-Duller's [33] study concluding that intrasentential code-switching is sometimes described as true code-switching. As such, the present study's finding has been of great value, especially to the aspect when the clear-cut border of the differences between code-switching and code-mixing has still been an endless debate among sociolinguists.

In contrast, this feature is found to be completely different in English-based code-switching. In English-based code-switching, interclausal (intersentential) switching is the most dominant, comprising $100 \%$ of the data. Table 6 clarifies this. This is not surprising. In English-based codeswitching, the embedded language (EL) is Indonesian. Since the respondents are native speakers of Indonesian, they automatically have a native-like competence in the language. Thus, such a competence allows them to freely and easily switch in any level of constituents during communication without fearing violating grammatical systems of either language.

Again, this phenomenon has lent strong support to the argument that a switch is also motivated by the speaker's competence in the embedded language. To some extent, people may switch back and forward in a single sentence because they have reasonable control of the embedded language. To different degrees, people also may switch during communication as they have difficulties maintaining the flow of communication using the language being used at that moment, for example, Indonesian students in English classrooms or in seminars in Indonesia where English is used as the primary medium of interaction.

The following figure (Figure 4) clearly illustrates the domination of interclausal switching type in English Indonesian code-switching (EICS).

As seen from Figure 4, interclausal switching ultimately underscores the other four switching types in EICS, taking $100 \%$ of the data. This phenomenon denotes that the respondents are likely to switch to a much larger constituent beyond the clausal boundary in code-switching between English and Indonesian. As mentioned previously, in EICS, the host language is English, and the embedded language or the guest language is Indonesian. As such, the respondents, 
TABLe 5: Types of Indonesian-English code-switching.

\begin{tabular}{lcccccc}
\hline \multirow{2}{*}{ No. } & \multirow{2}{*}{ Types of code-switching } & \multicolumn{2}{c}{ Speech interactions } \\
& & Seminars & Meetings & TV dialogues & Chitchats \\
\hline 1. & Intraclausal & $223(61.8 \%)$ & $87(55.8 \%)$ & $42(60 \%)$ & $15(40.5 \%)$ & $\mathbf{3 6 7}(\mathbf{5 8 . 8 \% )}$ \\
2. & Intraphrasal & $111(30.8 \%)$ & $32(20.5 \%)$ & $15(21.4 \%)$ & $8(21.6 \%)$ & $\mathbf{1 6 6}(\mathbf{2 6 . 6 \% )}$ \\
3. & Intralexical & $18(5.0 \%)$ & $29(18.6 \%)$ & $5(7.1 \%)$ & $8(21.6 \%)$ & $\mathbf{6 0}(\mathbf{9 . 6 \% )}$ \\
4. & Interclausal & $9(2.5 \%)$ & $5(3.2 \%)$ & $6(8.6 \%)$ & $6(16.2 \%)$ & $\mathbf{2 6}(\mathbf{4 . 2 \% )}$ \\
5. & Tag & 0 & $3(1.9 \%)$ & $2(2.9 \%)$ & 0 & $\mathbf{5 ( 0 . 8 \% )}$ \\
& Total & $\mathbf{3 6 1}$ & $\mathbf{1 5 6}$ & $\mathbf{7 0}$ & $\mathbf{3 7}$ \\
\hline
\end{tabular}

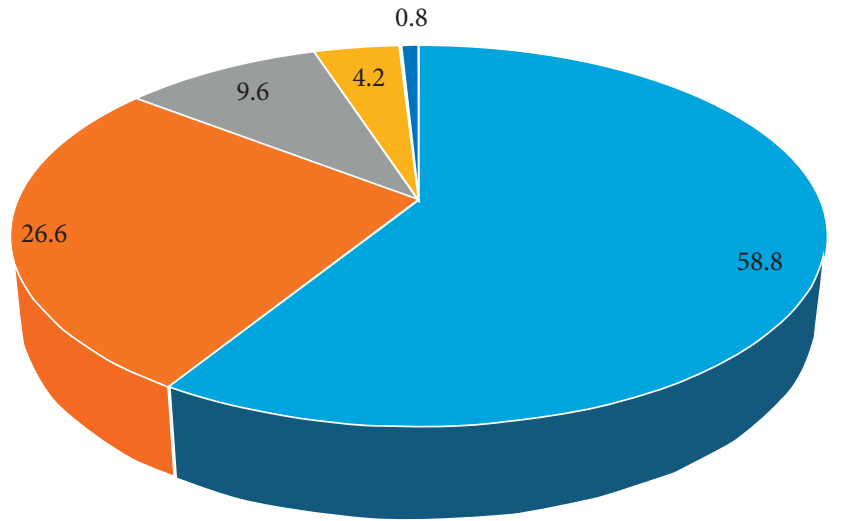

- INTRACLAUSAL

- INTRAPHRASAL

- INTERCLAUSAL

- TAG

- INTRALEXICAL

FIgure 3: Types of code-switching in IECS.

Table 6: The types of English-Indonesian code-switching.

\begin{tabular}{lccccc}
\hline \multirow{2}{*}{ Types of code-switching } & \multicolumn{9}{c}{ Sample codes } & \multirow{2}{*}{ Total } & $\%$ \\
& $\mathrm{H}$ & $\mathrm{W}$ & $\mathrm{Z}$ & & \\
\hline Intraclausal (Iracla) & - & - & - & - & - \\
Intraphrasal (Iraphra & - & - & - & - & - \\
Intralexical (Iralex) & - & - & - & - & - \\
Interclausal & 18 & 19 & 5 & 42 & 100 \\
Tag & 18 & 19 & 5 & 42 & 100 \\
Total & & & & & \\
\hline
\end{tabular}

without any hesitation, find it much easier for them to switch in any level of constituents as far as the language competence is concerned because they are native speakers of Indonesian.

Now, let us turn the discussion back to the configuration of code-switching between Indonesian and English (IECS). The ANOVA Friedman test confirms no significant difference in the switching types found among the four variables (where $x^{2} r=14.64,<$ the table value in both 0.05 and 0.01 levels, i.e., 21.03 and 26.20, respectively, given that $H_{0}$ is accepted). This implies that this pattern, a switch in Indonesian-English code-switching that is more likely to occur in minor constituents, can be universally applicable to other discourses and situations.

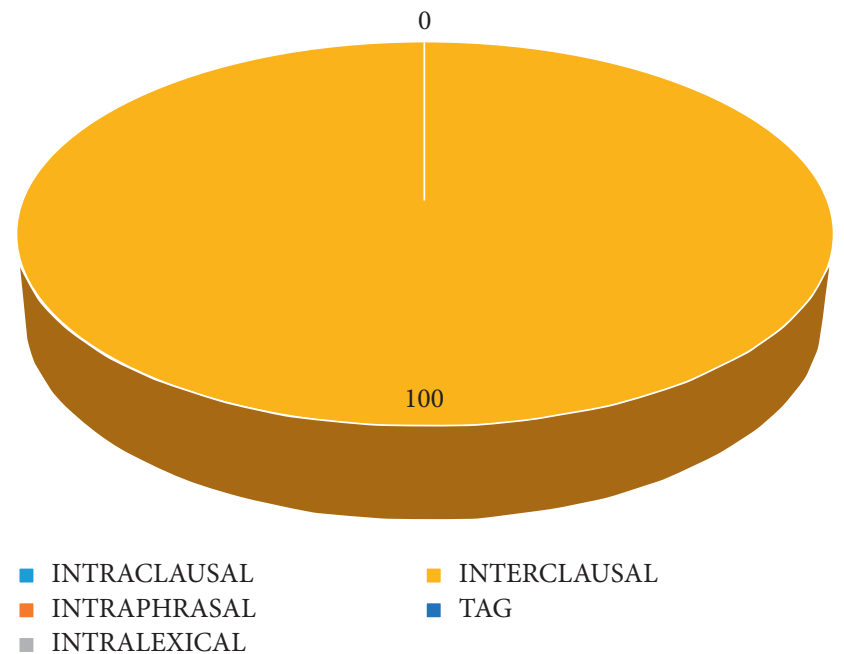

Figure 4: The dominant types of code-switching of EICS.

\section{Conclusion}

The present study has convincingly demonstrated that codeswitching between Indonesian and English (IECS) primarily occurs in more minor constituents such as within a clause boundary, a phrase boundary, and even within a word boundary rather than in major components such as within a sentence boundary as found significantly to occur in codeswitching between English and Indonesian (EICS). The former is well-known as intrasentential code-switching, whereas the latter is commonly known as intersentential code-switching. As such, it is found that nouns that occupy the syntactic roles of Indonesian-English switching discourse as subjects, objects of a verb, a preposition, and predicators to be significantly dominant among the switched segments.

Such domination then entails a switch between Indonesian noun phrases and English noun phrases, between Indonesian verbs and English objective noun phrases, between Indonesian conjunctions and English noun phrases or sometimes sentences, and between Indonesian prepositions and English noun phrases to be the most popular switched points and intraclausal switching to be the most frequent switching type in IECS. ANOVA Friedman's test confirms that these patterns can universally apply to any situation and form of interaction. 
It has been identified three factors underlying this noun domination. Firstly, nouns occupy the most significant portion of the syntactic role in an English sentence, comprising about two-thirds. Secondly, English use as a medium of communication in Indonesia is relatively low compared to those used as a second language like Malaysia and the Philippines. English is used occasionally in Indonesia as a foreign language, only in classrooms, seminars, and the likes. Finally, it may also be something to do with speakers' lack of English proficiency.

In consequence, they have a minimal choice of English constituent levels. For safety reasons, they are likely to switch to English in more minor constituents such as words and phrases rather than in major ones such as sentences. Otherwise, they will risk violating the grammatical system of either language. In addition, some theories such as "chunk" theory by Azuma [28] and "open and closed class items" theory by Joshi [29], and "islandhood" theory by Myerz-Scotton [30] may also lend strong support to the phenomenon where nouns are found to be the most popular switch segments in Indonesian-English codeswitching.

Outside of businesses, English code-switching is used to go from lower to higher levels of society, from individuals on the street to the country's president. There appears to be no rule for employing code-switching, or rather, the language norm and standards are neglected by society, resulting in recklessness and incorrect language utilization. While their position governing the upper level of society, the lower level of society is managed by no official office. In a nutshell, the higher level of society has complexity in applying the English code-switch, but the lower level of society has flexibility, which leads to erroneous language use. This error and fallacy in English use have become a media platforms pun that makes people chuckle.

The English code switch is a phenomenon of the English language that can occur in any situation and communication in Indonesia. Language restores dignity and retains a status, and everyone needs to maintain their standing. A position can be upgraded through language, and if a "sufficient usage" of a foreign language cannot be achieved, the code switch to English can.

More research needs to be done to learn more about English code-switching in the Indonesian context. More and more social media are being used, and more and more individuals are using such social media. Language is used as a tool for communication, and people are free to use whichever language they desire, even a combination of two or more languages. It is interesting to look at how Indonesians utilize English to communicate messages. This also applies to persons and nations for whom English is not their native language.

The current study's findings have various significant consequences for society, notably among Indonesian authors. To begin with, Indonesia is a multiethnic and multilingual country comprising many smaller minority populations. Therefore, the usage of numerous dialects and languages highlights this intriguing trait of Indonesians and symbolizes our distinct identities and cultures.
Finally, more research is required to understand both the impact and the benefits of code-switching as a linguistic device that connects one multilingual society in unique ways that only members of that society can understand. This, in specific ways, contributes to a sense of belonging and unity among members of the community. Aside from this, codeswitching helps introduce one civilization to another and pushes individuals to tolerate differences and celebrate diversity more intriguingly and less traditionally.

\section{Data Availability}

The data can be requested through contact with the corresponding author upon reasonable request.

\section{Conflicts of Interest}

The authors declare that they have no conflicts of interest.

\section{References}

[1] R. K. Rahardi, Sosiolinguistik, Kode Dan Alih Kode, Pustaka Pelajar, Yogyakarta, Indonesia, 2001.

[2] D. Setiawan, "English code switching in Indonesian language," Universal Journal of Educational Research, vol. 4, no. 7, pp. 1545-1552, 2016.

[3] J. J. Gumperz, "The sociolinguistic significance of conversational code-switching," RELC Journal, vol. 8, no. 2, pp. 1-34, 1977.

[4] J. J. Gumperz, Discourse Strategies, Cambridge University Press, Cambridge, UK, 1982.

[5] G. Sankoff, Social aspects of multilingualism in New Guinea, Ph.D. dissertation, McGill University, Montreal, Canada, 1968.

[6] G. Sankoff, "Language use in multilingual societies: some alternative approach," in Sociolinguistics, J. B. Pride and J. Holmes, Eds., Penguin, Middlesex, UK, 1972.

[7] N. Denison, "Some observation on language variety and pluralingualism," in Sociolinguistics, J. B. Pride and J. Holmes, Eds., pp. 65-77, Penguin, Middlesex, UK, 1971.

[8] H. Motschenbacher, "Code-switching practices in ESC performances," Language, Normativity, and Europeanisation, Palgrave Macmillan, London, UK, pp. 153-187, 2016.

[9] E. Marasigan, Code Switching and Code Mixing in Multilingual Societies, SEAMEO Regional Language Centre, Singapore, 1983.

[10] W. Li, "Three generations, two languages, one family: language choice and language shift in a Chinese community in Britain," Multilingual Matter: Clevendon, vol. 221, 1994.

[11] R. D. W. Widaya, "English-Indonesian code-switching in indonesian song lyrics composed by Melly Goeslow," 2015, http://karya-ilmiah.um.ac.id/index.php/sastra-inggris/article/ view/2913.

[12] N. Hasselmo, "Code Switching as order selection," in Studies for Einar Haugen, E. Finchow, Ed., Mouton, The Hague, Netherlands, 1972.

[13] N. Hasselmo, "Code switching and modes of speaking," in Texas Studies in Bilingualism, G. Gilbert, Ed., Walter de Gruyter and Co., Berlin, Germany, 1979.

[14] M. Schiegg, "Code-switching in lower-class writing: autobiographies by patients from southern German psychiatric hospitals (1852-1931)," Journal of Historical Sociolinguistics, vol. 2, no. 1, pp. 47-81, 2016. 
[15] R. Gingras, "Problems in the description of Spanish- English intra-sentencial code switching," in Southwest Areal Linguistics, G. Bills, Ed., Institute for Cultural Pluralism, San Diego, CA, USA, 1974.

[16] E. K. Amuzu, "Socio-pragmatics of conversational codeswitching in Ghana," Ghana Journal of Linguistics, vol. 1, no. 2, pp. 1-22, 2012.

[17] L. A. Timm, "Spanish-English code switching: elporque y how not-to," Romance Philology, vol. 28, no. 4, 1975.

[18] L. A. Timm, "Code-switching in war and peace," in Aspect of Bilingualism, M. Paradis, Ed., Hornbeam, Columbia, SC, USA, 1978.

[19] T. Mokgwathi and V. Webb, "The educational effects of codeswitching in the classroom-benefits and setbacks: a case of selected senior secondary schools in Botswana," Language Matters, vol. 44, no. 3, pp. 108-125, 2013.

[20] C. F. Hockett, A Course in Modern Linguistics, Macmillan, New York, NY, USA, 1958.

[21] A. H. Yassi, "Indolish (Indonesian-English): toward a typology of Indonesian-English code-switching," Analisis, vol. 4, pp. 235-252, 2001.

[22] E. McClure, "The Relationship between form and functions in written national language-English code-switching: evidence from Mexico, Spain, and Bulgaria," in Code-switching Worldwide, R. Jakobson, Ed., pp. 125-152, Mouton de Gruyter, Berlin, Germany, 1998.

[23] S. Poplack, "Sometime I'll start a sentence in English y terminoenespanol: toward a typology of code switching," Linguistics, vol. 18, no. 7-8, pp. 581-616, 1980.

[24] A. H. Yassi, "Code switching as a communication strategy in Indonesian-English bilingual discourses: a congruencefunctional approach to Indonesian-English code switching," Universitas Hasanuddin, Makassar, Indonesia, Disertasi, 2003.

[25] A. H. Yassi, "Effective numbers of small group work members in improving learners' speaking competence in English grammar classrooms: interactive vs. conventional teaching method," Asian ESP Journal, vol. 16, no. 12, 33 pages, 2020.

[26] K. Maming, "A preliminary study on teacher's voices: their problems in ELT and content-based instruction (CBI)," Journal of ASIA TEFL, vol. 17, no. 2, pp. 707-714, 2020.

[27] S. Romaine, Bilingualism, Basil Blackwell Ltd., Oxford, UK, 1991.

[28] S. Azuma, "Meaning and form in code-switching," in CodeSwitching Worldwide, R. Jacobson, Ed., pp. 109-124, Mouton de Gruyser, Berlin, Germany, 1998.

[29] A. K. Joshi, Processing of sentences with intrasentential codeswitching, Dowty, L. Karttunen, and A. Zwicky, Eds., pp. 190-205, Natural Language Parsing, Cambridge University Press, Cambridge, UK, 1985.

[30] C. Myerz-Scotton, "Common and uncommon ground: social and structural factors in code switching," Language in Society, vol. 22 , no. 3, pp. 475-503, 1993 b.

[31] J. J. Gumperz and E. Hernandez, "Bilingualism, bidialectalism, and classroom interaction," in Language in Social GroupsStanford University Press, Stanford, CA, USA, 1971.

[32] J. J. Gumperz, "Linguistic and social interaction in two communities," in Language in Social Group, J. Gumperz, Ed., pp. 311-339, Stanford University Press, Stanford, CA, USA, 1964.

[33] J. Treffers-Duller, French-Dutch Language Mixture in Brussels, University of Amsterdam Dissertation, Amsterdam, Netherlands, 1991. 